\title{
A Review of Heavy-Duty Vehicle Powertrain Technologies: Diesel Engine Vehicles, Battery Electric Vehicles, and Hydrogen Fuel Cell Electric Vehicles
}

\author{
Carlo Cunanan, Manh-Kien Tran (D), Youngwoo Lee, Shinghei Kwok, Vincent Leung and Michael Fowler*D
}

check for updates

Citation: Cunanan, C.; Tran, M.-K.; Lee, Y.; Kwok, S.; Leung, V.; Fowler, M. A Review of Heavy-Duty Vehicle Powertrain Technologies: Diesel Engine Vehicles, Battery Electric Vehicles, and Hydrogen Fuel Cell Electric Vehicles. Clean Technol. 2021, 3, 474-489. https://doi.org/10.3390/ cleantechnol3020028

Academic Editor: José-Santos

López-Gutiérrez

Received: 24 March 2021

Accepted: 25 April 2021

Published: 1 June 2021

Publisher's Note: MDPI stays neutral with regard to jurisdictional claims in published maps and institutional affiliations.

Copyright: (c) 2021 by the authors. Licensee MDPI, Basel, Switzerland. This article is an open access article distributed under the terms and conditions of the Creative Commons Attribution (CC BY) license (https:// creativecommons.org/licenses/by/ $4.0 /)$.
Department of Chemical Engineering, University of Waterloo, 200 University Avenue West, Waterloo, ON N2L 3G1, Canada; cjcunanan@uwaterloo.ca (C.C.); kmtran@uwaterloo.ca (M.-K.T.); youngwoo.lee@uwaterloo.ca (Y.L.); s7kwok@uwaterloo.ca (S.K.); v28leung@uwaterloo.ca (V.L.)

* Correspondence: mfowler@uwaterloo.ca; Tel.: +1-519-888-4567 (ext. 33415)
Abstract: Greenhouse gas emissions from the freight transportation sector are a significant contributor to climate change, pollution, and negative health impacts because of the common use of heavy-duty diesel vehicles (HDVs). Governments around the world are working to transition away from diesel HDVs and to electric HDVs, to reduce emissions. Battery electric HDVs and hydrogen fuel cell HDVs are two available alternatives to diesel engines. Each diesel engine HDV, battery-electric HDV, and hydrogen fuel cell HDV powertrain has its own advantages and disadvantages. This work provides a comprehensive review to examine the working mechanism, performance metrics, and recent developments of the aforementioned HDV powertrain technologies. A detailed comparison between the three powertrain technologies, highlighting the advantages and disadvantages of each, is also presented, along with future perspectives of the HDV sector. Overall, diesel engine in HDVs will remain an important technology in the short-term future due to the existing infrastructure and lower costs, despite their high emissions, while battery-electric HDV technology and hydrogen fuel cell HDV technology will be slowly developed to eliminate their barriers, including costs, infrastructure, and performance limitations, to penetrate the HDV market.

Keywords: heavy-duty vehicles; diesel engine trucks; battery electric trucks; fuel cell electric trucks; zero-emission vehicles

\section{Introduction}

Increasing truck transport demand [1] and greenhouse gas emissions [2] have garnered the interest of many to research alternative powertrain technologies for heavy-duty vehicles (HDVs). Objectives to reduce and mitigate emissions across all sectors have been set by many governments regarding the transportation sector. Conventional HDVs disproportionately represent the on-road carbon dioxide $\left(\mathrm{CO}_{2}\right)$, nitrogen oxide $\left(\mathrm{NO}_{\mathrm{x}}\right)$, and particulate matter (PM) [3]. Medium and heavy-duty vehicles account for approximately $23 \%$ of the greenhouse gas (GHG) emissions in the United States [4]. HDVs also account for approximately $40-60 \%$ of the $\mathrm{NO}_{\mathrm{x}}$ and $\mathrm{PM}$ emissions [3]. Climate change, pollution, and the resulting health impacts are some of the major concerns with the rise of these combustion emissions [5]. Therefore, the proposal for lower emission and zero-emission HDVs has been made.

A vehicle is classified as heavy-duty if it has a gross vehicle weight rating (GVWR) greater than 26,000 lbs [6]. The GVWR is the maximum loaded weight of the vehicle, which is the weight of the vehicle in addition to its payload. HDVs can be further classified into two classes, as seen in Figure 1. Class 7 vehicles include transit buses, tow trucks, and furniture trucks. Class 8 vehicles include semi-tractors, fire trucks, and dump trucks. Class 7 vehicles have a GVWR of 26,000 lbs to 33,000 lbs, and Class 8 vehicles have a GVWR of greater than $33,000 \mathrm{lbs}$. 
Class 7: 26,001 to $33,000 \mathrm{lbs}$.
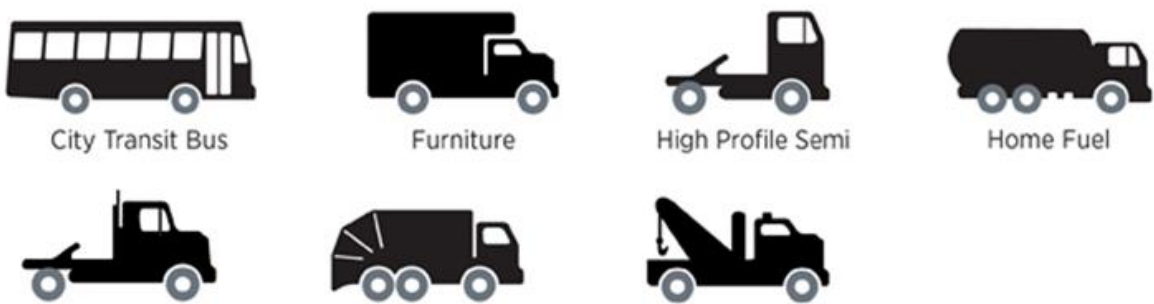

Medium Semi Tractor
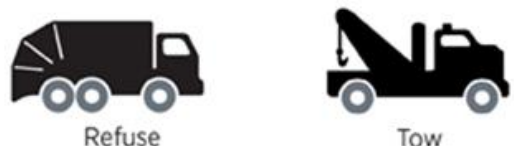

Tow

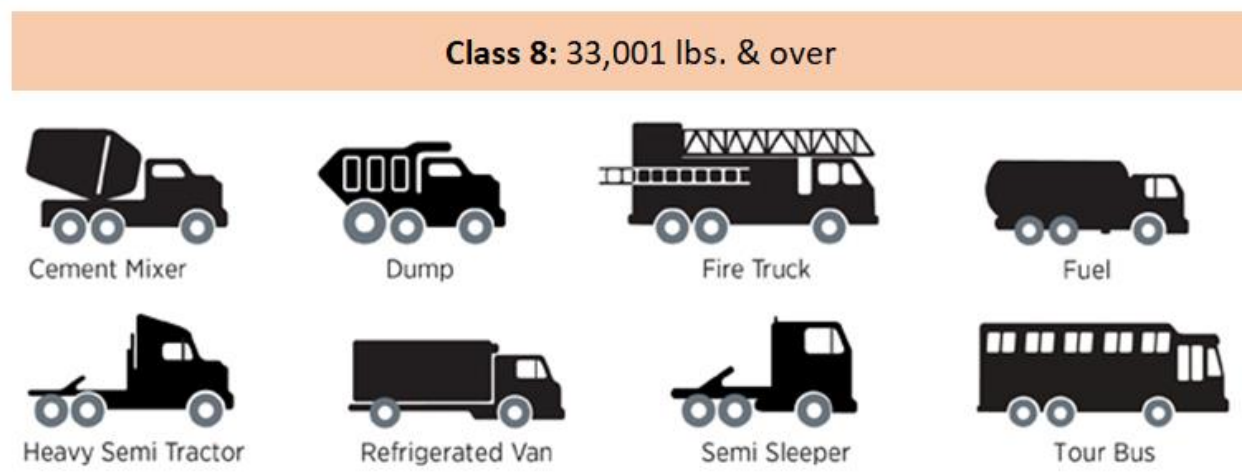

Figure 1. Classes and applications of heavy-duty vehicles.

Conventional HDVs use fossil fuels and an internal combustion engine (ICE) which produce energy to power their movement [7]. Most HDVs today use an ICE that utilizes diesel called a compression-ignition engine due to its greater energy efficiency than gasoline. However, many kinds of emissions are released during diesel combustion, such as $\mathrm{CO}_{2}, \mathrm{NO}_{\mathrm{x}}$, and PM. Lower emission strategies in HDV technology consist of increasing the efficiency or reducing the pollution of the conventional diesel truck [8], using alternative fuels which produce fewer emissions [9], or using a hybrid-electric powertrain that stores some of the energy it uses within batteries [10]. These strategies work by reducing fuel consumption or by reducing their tailpipe emissions. Examples of lower emission strategies include reducing the rolling resistance of the tires, which increases the fuel savings of the vehicle and using alternative fuels such as compressed natural gas or biodiesel, which produce fewer emissions [11]. However, zero-emission vehicles require a different powertrain as any vehicle with an ICE will result in tailpipe emissions.

The two types of zero-emission vehicles that will be discussed in this review are battery electric vehicles (BEVs) and hydrogen fuel cell vehicles (HFCVs). These vehicles propel themselves using electricity and do not require the use of an ICE. BEVs and HFCVs both convert the chemical energy stored in active materials into electrical energy within the electrochemical cells. Batteries differ from fuel cells because batteries have the active material stored within the system, while fuel cells have the active materials continuously fed into the system. BEV batteries are often composed of lithium-ion cells due to their high energy and power density [12-14]. On the other hand, HFCVs often use proton exchange membrane fuel cells (PEMFC) due to their high-power density and cold-start capabilities [15].

Both solutions offer zero tailpipe emissions, however, their well-to-wheels (WTW) emissions are still high in many countries because of fossil fuel energy generation. WTW emissions are the emissions released from two main stages: well-to-pump, and pumpto-wheels [16]. Well-to-pump emissions are the emissions released from the production of energy and the transport of it to the consumer. Pump-to-wheels are the refueling and tailpipe emissions generated when the vehicle is being refueled and used, respectively. Therefore, if the energy to generate the electricity or hydrogen to power the vehicle was uti- 
lized fossil fuels, the well-to-pump emissions would be significant. However, if the sources of energy used to generate the energy in these zero-emission vehicles were renewable and not fossil-fuel related, they would theoretically have zero emissions [17].

In recent years, many researchers have been working to either improve the traditional diesel powertrain or develop battery and fuel cell electric powertrains for HDVs. With that, there have also been some works that provided a comparison between different powertrains or analysis of their impacts based on economic, environmental, and social aspects. Zhao et al. [18] proposed several non-electrification efficiency-improving technologies as well as hybrid powertrain technologies to reduce heavy-duty truck fuel consumption. It was found that improvements in engine efficiency, aerodynamic drag, and rolling resistance would result in $6-13 \%$ in fuel savings, while hybridization was found to achieve $16 \%$ fuel saving. Sen et al. [19] compared traditional diesel, biodiesel, compressed natural gas, hybrid, and battery electric HDVs based on life-cycle emissions, costs, and externalities, to gain insights on how alternative fuel technologies could be employed in HDVs. The results showed that overall, battery-electric HDVs outperformed all other types of trucks. Assuming that electricity could be produced from renewable energy sources in the future, the use of a battery-electric powertrain would significantly improve the life cycle cost of trucks as well as the air quality through emissions reduction. Shin et al. [17] conducted a case study using a conjoint survey with 1049 people and a mixed multiple discrete-continuous extreme value model to analyze consumer preferences between battery electric vehicles and fuel cell vehicles. The results indicated that consumers preferred battery-electric vehicles over fuel cell vehicles. In [9], the authors presented a summary of market diffusion studies for alternative fuels and powertrains in HDVs. The methods, main findings, and policy recommendations in each study were compared and synthesized to identify the strengths and weaknesses of each type of powertrains. It was found that there was a high degree of uncertainty regarding which HDV powertrain was superior compared to the rest. Smallbone et al. [20] evaluated the potential impact of several HDV powertrain technologies, including conventional diesel engines, hybrid, battery-electric, hydrogen fuel cells, and free-piston engine generators. The analysis in this study showed that the benefits of improved electrical powertrains, onboard storage, efficiency improvements, and vehicle design could result in increased competitiveness for battery electric and hydrogen fuel cell vehicles in the future. Despite the findings given in these studies, in general, there has not been an up-to-date and complete review of recent technology developments for HDV powertrains or comparison between these powertrains based on their future potentials. This study aims to provide a comprehensive review of the most recent HDV powertrain technologies, including developments in diesel engine, battery-electric, and hydrogen fuel cell HDVs, as well as a comparison between these powertrains based on various criteria. The studies discussed in this paper were selected as they provided key background information or recent developments regarding diesel and zero-emission HDV powertrain technologies in terms of costs, efficiency, infrastructure, and so on. The information presented in this study will be useful for researchers who are looking to improve their HDV powertrain technology of interest, as well as for decision-makers who are trying to decide the appropriate future direction for HDV powertrain developments.

The rest of the paper is organized as follows. Sections 2-4 discuss diesel, battery, and hydrogen fuel cell heavy-duty powertrain technologies, respectively. Section 5 provides a comparison of the different technologies and their future perspectives. Finally, Section 6 outlines some concluding remarks.

\section{Diesel Internal Combustion Engine in Heavy-Duty Vehicles}

Internal combustion engines use transport fuel and combustion to propel their movement. There are two major types of internal combustion engines: compression-ignition (CI) and spark-ignition (SI) [21]. Most conventional heavy-duty vehicles use CI engines while passenger vehicles use SI engines. Both use the four-stroke combustion cycle of intake, compression, combustion, and exhaust. However, their difference lies in the way they 
ignite their fuel and the type of fuel they use, which results in differences in efficiencies. CI engines use the heat from the compression stroke to ignite the fuel, while the SI engine uses spark plugs [22]. As well, CI engines use diesel fuel which has 10-15\% more energy content than gasoline [23] which is used in SI engines. Compression values of diesel engines are higher, which leads to higher efficiencies as the likelihood that air molecules will react with the molecules in the fuel is greater. The greater energy density and the higher efficiencies make it the most popular fuel engine to date for HDVs.

A simplified conventional diesel powertrain configuration involves the engine, clutch, and transmission. The transmission converts the torque output from the engine to rotations in the axles. This is a result of engines running at higher rotations per minute than the average vehicle's wheels. The clutch allows for the disconnection between the transmission and the engine. The engine is also connected to an alternator which transfers energy to a battery. The battery is then connected to electrical accessories and is used to start the engine alongside the starter.

Conventional HDV ranges can vary depending on the existing payload and fuel in the truck. The average mileage per gallon of fuel for each truck is around $6.5 \mathrm{mpg}$ [24]. As well, a truck can typically carry around 150-300 gallons of fuel. The range that this allows for is around 975-1950 miles without any stops to refuel. However, this range is highly dependent on the topology, the traffic, and the fact that truckers would not consume $100 \%$ of the fuel at each run. The average flow rates are 20-30 gallons per minute for a diesel pump results in a refueling time of a 300-gallon capacity truck of around 10-15 min [25].

Diesel HDVs release three major types of emissions: carbon oxides, nitrogen oxides, and particulate matter [26]. There are other components, such as sulfur oxides and organic compounds that are released, but they are not analyzed in this report. Emissions from HDVs tend to vary widely depending on the weight, driving cycle, age, terrain, injection timing, and after-treatment of the vehicle and its engine [27]. According to a study by Seo et al., an HDV with a GVWR from 26,000 lbs to 88,000 lbs can emit $\mathrm{CO}_{2}$ from $29 \mathrm{~g} / \mathrm{km}$-ton to $119 \mathrm{~g} / \mathrm{km}$-ton, respectively [28]. The Canadian National Railway, on average, estimates that a heavy-duty truck will emit around $63.8 \mathrm{~g} / \mathrm{km}$-ton of $\mathrm{CO}_{2}$ with an average shipment of 16 tons $(35,200 \mathrm{lbs})$ [29]. Regarding $\mathrm{NO}_{\mathrm{x}}$ emissions, the average truck will emit around $7 \mathrm{~g} / \mathrm{mile}$, which, compared to a conventional gasoline car, is greater by a factor of 10 [30]. To combat emissions, after-treatment system technology can be installed, which processes some of the exhaust gases into non-harmful substances. For example, selective catalytic reduction technology uses the reactions between ammonia and $\mathrm{NO}_{\mathrm{x}}$ through a catalyst to form nitrogen and water vapor [11]. This aids in reducing the amount of $\mathrm{NO}_{\mathrm{x}}$ that is released into the environment.

The current infrastructure for diesel HDVs is highly prevalent and it is available in most, if not all, countries. As of 2019, nearly all the HDV market runs on conventional diesel fuel $[9,31]$. The demand for alternative fuels is increasing for HDVs, but the alternative fuels markets are still in the very early stages. Regarding energy efficiency, diesel engines, from tank-to-wheel, on average, are around 23\% energy efficient [32]. This means that out of the available energy at the fuel tank, only $23 \%$ of it is used as actual work, with the rest being lost due to heat and friction. The specific energy of diesel fuel is around $42.9 \mathrm{MJ} / \mathrm{kg}$ [33].

\section{Recent Technological Developments in Diesel Engine Heavy-Duty Vehicles}

Some recent studies have shown development in diesel engine HDV powertrain, aiming to reduce emissions and improve efficiency. Bhoopalam et al. [34] conducted a literature review on the technique of truck platooning to reduce the fuel consumption of trucks. Truck platooning is virtually linking multiple semi-autonomously driven trucks together on the road. This reduces aerodynamic drag and places trucks closer together. Advantages of truck platooning shown in the study included cost savings and fewer emissions from the reduced fuel consumption, and better use of road capacity. Peng et al. [35] utilized the software AVL CRUISE and a multi-island genetic algorithm to optimize the 
powertrain transmission ratio of a heavy-duty truck with 142,659 datasets of road operation in China. By using the vehicle performance simulation models HTDC-1800 driving cycle, an optimal powertrain transmission ratio was obtained. This allowed for the fuel consumption to decrease by $8.19 \%$. Henriksson et al. [36] utilized dynamic programming in the optimization of gear selection and engine torque to reduce fuel consumption without the increase of trip time of a heavy-duty vehicle. Using MATLAB and a $66 \mathrm{~km}$ driving cycle with 53 stops, they found that coasting in neutral even on flat surfaces, also known as pulse-and-gliding, can be used to optimize fuel usage. They were able to reduce fuel consumption by $12.7 \%$ in their simulation. Emanuele et al. [37] evaluated the effects on performance and emissions that the addition of poly(oxymethylene) dimethyl ethers (POMDME) had on diesel blends. This is promising as it does not require any changes to the existing diesel infrastructure in the engine or pumps. Exhaust soot and gas analysis was conducted, and they found that POMDME blends had significant soot emission reductions of up to $34 \%$ with no reduction in thermal efficiency and no change in nitrogen oxide emissions. Ramesh et al. [38] evaluated the effects that cylinder deactivation (CDA) can have on a diesel engine. CDA is the deactivation of valves at certain times to reduce the air-fuel ratio. This resulted in higher exhaust gas temperatures and lower exhaust gas flow rates which reduce pumping work and improves fuel efficiency. Depending on the engine speed, CDA provided a brake-thermal-efficiency improvement of 5-32\%, increased rate of after-treatment warm-up, and higher steady-state temperatures. This increase in efficiency reduced the motoring torque required, which can help the after-treatment system stay warm and reduce fuel costs. Shim et al. [39] compared various advanced combustion technologies (ACTs) that have shown a potential to reduce nitrogen oxide and particulate matter emissions in comparison with conventional diesel combustion. The emission performance and the thermal and combustion efficiencies were criteria used to compare homogenous charge compression ignition, premixed charge compression ignition, and dual-fuel premixed charge compression ignition engines with the conventional diesel combustion engine. The paper stated that all the ACTs can be used to reduce the $\mathrm{NO}_{\mathrm{x}}$ and PM emissions to a level of the Euro VI standards without an after-treatment system. However, the total hydrocarbon emissions were still very high for all the ACTs, with almost 7.8 times to 38 times more total hydrocarbon (THC) emissions than a conventional diesel engine. $\mathrm{Xu}$ et al. [40] conducted a review of the usage of organic Rankine cycle (ORC) waste heat recovery systems in heavy-duty engines; this is the recovery of heat because of the combustion of the fuel to use in other applications within the heavy-duty truck. They analyzed the various heat sources that can be used, different heat exchanger designs, expander design, and the working fluid selection. As well, they reviewed the control strategies used for the system was done. There was a large disparity of ORC power production in simulation and experimental studies. Vos et al. [41] studied the effect that delayed intake valve closure timing will have on fuel savings. The delayed intake valve closure timing enabled higher exhaust gas recirculation fractions. They showed that there were steady-state fuel economy benefits that could be achieved for a heavy-duty Cummins diesel engine during high-speed moderate to high load operating conditions. Fuel savings of 1.2 and $1.9 \%$ were demonstrated at $2200 \mathrm{rpm}$ for 12.7 and 7.6 bar brake mean effective pressure operating conditions. Hlasny et al. [42] reviewed the optimization of fuel consumption using powertrain control and intelligent transportation systems. To optimize an HDV without changing fuel or existing infrastructure, a planned-out route, considering the road traffic, slope, and weather was necessary. Moreover, speed control and driver behavior must be considered for improved fuel consumption. Forecasts about traffic and weather should be gathered to reroute, and recommendations of cloud-based architecture to integrate these approaches should be made.

\section{Battery Electric Powertrain in Heavy-Duty Vehicles}

BEVs use battery packs to power electric motors for their propulsion. The most common type of battery proposed for battery power packs in battery HDVs is lithium-ion 
due to its high energy density, high energy efficiency, and long lifespan [43,44]. At its most basic level, a lithium-ion battery cell consists of a cathode and lithium anode along with a separator and electrolyte solution. During discharge and charge, lithium ions are carried by the electrolyte from the cathode to the anode and vice-versa, respectively, through the separator, which generates an electron current. All battery power packs must come with a battery management system. This system monitors the battery's state of charge (SOC), state of health (SOH), state of energy (SOE), and more [45]. This component is vital to ensure safe and reliable vehicle operation.

The powertrain of a BEV consists of the battery pack, the DC/AC inverter, and the electric motors. This powertrain is much simpler than that of a conventional diesel truck as there are not as many mechanically moving parts as there is no engine. This simplicity is part of the reason why BEVs have 20-30\% lower maintenance costs when compared to conventional gas or diesel-powered vehicles [14]. Additionally, most BEVs also have regenerative braking capabilities. This system works by capturing the kinetic energy that would usually be lost when braking in a conventional vehicle [46]. In most other vehicles, braking works by pressing brake pads onto rotors attached to the axle. This creates friction that decelerates the vehicle, but the kinetic energy of the car gets converted into thermal energy at the brake pads and is lost to the environment. The practice of regenerative braking serves to extend the driving range and reduce wear on conventional brake pads.

The range for a battery HDV depends on the type of battery and weight of the vehicle. The battery range for a typical battery freight vehicle is around $100-200 \mathrm{~km}$ on a single charge $[47,48]$. However, Tesla's semi-truck claims to be able to travel $800 \mathrm{~km}$ on a full charge [49]. The major concerns are the weight of the battery in relation to the capacity required with freight vehicles. A heavier battery is required for longer ranges which would require greater energy and power output. For an $800 \mathrm{~km}$ range, the battery capacity required would be around $1000 \mathrm{kWh}$ of energy which would require at least $5500 \mathrm{~kg}$ $(12,000 \mathrm{lbs})$ dedicated to the battery with current energy densities [50].

The recharging time for a battery HDV depends on the type of charger and the capacity of each truck. A truck would need a level 3 charger, which can output power greater than $25 \mathrm{~kW}$. At this power output, the recharging time would be around $20 \mathrm{~h}$ for a $1000 \mathrm{kWh}$ battery. However, with power outputs at a speculated $1 \mathrm{MW}$, the recharging time could theoretically be reduced to $1 \mathrm{~h}$. However, fast charging has had negative implications in concern with degradation as faster charging can result in shorter overall battery life [51]. Current technology has the capability of charging at $50 \mathrm{~kW}$ [52]. The tailpipe emissions of a battery HDV, as with any zero-emission vehicle, are zero; however, the current infrastructure for battery HDVs is limited. Tesla announced in 2017 that they plan to implement a network of "megachargers" for their upcoming Tesla Semi. The "megacharger" would deliver over $1 \mathrm{MW}$ of power so that Semi could be charged in a relatively short period of time [53]. However, as of 2020, none of these megachargers have been deployed publicly. Gallo estimates that one charger installation would cost between $\$ 17000$ and $\$ 32,000$ for a low-powered $16.5 \mathrm{~kW}$ charger, with prices increasing up to between $\$ 150,000$ and $\$ 200,000$ for a more powerful, $450 \mathrm{~kW}$ charger [54]. Due to the lack of current battery HDVs on the market, there has been little heavy-duty BEV infrastructure deployment so far. However, there is a growing number of regular electric vehicle charging stations that have been installed across North America [55] that can potentially be fitted for HDVs. This will simply just take much more time and consume a lot more power in recharging due to the higher battery capacities required in HDVs.

The tank-to-wheel efficiency for a BEV is averaged to be around $68 \%$, with a range of $64.4 \%$ to $86 \%$ [32]. The losses would be due to the friction in the powertrain, and the electrical resistances in the transport of electricity. This varies depending on the battery type and the electrical resistances involved. The specific energy of a Li-ion battery depends on the design and characteristics, but they range from 120-220 Wh/kg [56]. The lifespan of a battery in freight BEVs is around 6 years-1000 to 2000 deep cycle life-due to battery degradation [48]. This is often categorized as the time that it takes for the capacity 
of the battery to reach $70-80 \%$ of the original capacity [57]. However, this lifespan is dependent on temperature, type of application, and the state of charge [58]. To compete with conventional diesel engines, the goal for electric drive vehicles is to reach a lifespan of around 10-15 years.

\section{Recent Technological Developments in Battery-Electric Heavy-Duty Vehicles}

Recent studies have shown development and breakthrough in vehicle powertrain that are powered by battery systems. Mareev et al. [59] analyzed a BEV's energy consumption, required battery capacity, and charging infrastructure by using a battery-electric truck simulation model parameterized based on the desired transportation scenario. Furthermore, restrictions such as payload, charging infrastructure cost, and battery aging model were integrated into the statistical prediction. The authors compared the result to a conventional heavy-duty truck simulated in the same scenario and concluded that BEVs could perform on the same cost level as diesel trucks in certain scenarios and were 2.5 times more efficient energy output than the simulated diesel trucks. Verbruggen et al. [60] conducted an energetic benefit comparison between a multi-speed transmission and a single-speed transmission for a battery-electric heavy-duty long-haul truck and analyzed their energetic benefits under the Vehicle Energy Consumption Calculation Tool (VECTO) reference. The result showed that for a given long-haul drive cycle, a multi-speed transmission enables reduction of electric machine size by $16 \%$ and the energy consumption is reduced by $1-2 \%$, without any reduction in top speed and acceleration performance. Ghandriz et al. [61] studied the profitability of automated driving systems (ADS) and electrification for heavy vehicles by implementing mathematical optimization models that parameterized vehicle dynamics, vehicle size, charging stations distance, etc. which in total constituted 3072 scenarios. Profitability was determined by evaluating the total cost of ownership (TCO) and it was shown that ADS and electrification incorporation reduced TCO by $20 \%$. Pelletier et al. [14] presented an overview of BEVs technology and the potential of electric vehicles (EVs) in the goods distribution sector, with focuses on the most relevant current situation information, including market penetration, EVs market adaptation analysis, and incentives for EVs adoption. The authors closed the gap between the gains of EVs scientific research and the lack of goods distribution strategies and suggested government incentives are necessary to overcome the high initial cost barrier for market penetration. Schulte et al. [62] analyzed the electric road systems (ERS) using the Strategic Sustainable Development Framework, which assesses ERS sustainability in relation to freight transport. The study results showed that ERS has the potential to decrease the environmental impact of freight transport considerably if it is powered by renewable energy. In addition, environmental benefits could be paid back in less than five years if freight traffic volumes were sufficiently high. Sen et al. [63] assessed the impact of automated diesel and battery electric heavyduty trucks in terms of environmental, economic, and social aspects with 20 macro-level indicators. The resulting analysis suggested that policymakers should drive people to consider alternative energy sources to reduce GHG emissions generated by electricity generation in the United States for batteries. In [64], the authors investigated the energy consumptions of overhead catenary trucks under different configurations for the traction battery and catenary power system. They also compared the results to their previous study findings and concluded that the energy consumption of the overhead catenary trucks was approximately the same as a battery-electric truck and about half of the equivalent energy consumption of a conventional diesel truck. Wolff et al. [65] showed the influence of the powertrain topology and the associated efficiency and energy consumption under the design of commercial electric machines. The results from the study showed that singlemachine topologies offer efficiency advantages compared to multiple-machine topologies. Also, the study highlighted a joint consideration of application-specific machine design and topology to maximize the full technological potential. 


\section{Hydrogen Fuel Cell Electric Powertrain in Heavy-Duty Vehicles}

FCEVs operate similarly to BEVs because they are both driven by electric motors. However, unlike BEVs, FCEVs rely on a hydrogen fuel cell to provide the electric motor's power. Hydrogen fuel cells are electrochemical devices that convert the chemical energy of hydrogen into electricity, heat, and water. Since there is no combustion required to generate usable energy, FCEVs have the benefit of having zero tailpipe emissions. A typical PEMFC is used by ionizing hydrogen atoms from the fuel tank at the anode [66]. Then, the hydrogen protons pass through the proton exchange membrane, where they react with oxygen and form water as a by-product. Meanwhile, the electrons stripped from the hydrogen fuel can be used to power the electric motors of the vehicle or charge the vehicle's battery. In addition to the PEMFC, there are various other types, including alkaline (AFC), phosphoric acid (PAFC), solid oxide (SOFC), molten carbonate (MCFC), and more [67].

The fuel cell HDV powertrain is like the battery HDV. They both contain batteries and have their energy sources connected to electric motors that power their propulsion. As well, they both would have regenerative braking capabilities, which recharge batteries in the deceleration of the system [68]. The difference is the main energy source itself. FCEVs use fuel cell stacks and hydrogen as their main energy source, while BEVs would use batteries. FCEVs would use a battery for fuel cell start-up, capture regenerative braking energy, provide extra power during accelerations, and aid in low-speed propulsion as fuel cells would be at a low-efficiency region [69]. There has also been work done in vehicle powertrains that contain ultracapacitors instead of batteries, or ultracapacitors and batteries together alongside the fuel cell to aid in additional energy storage and distribution [70]. The energy from the fuel cell stack would be transferred to a DC / AC inverter which adjusts the voltage levels [71]. Then, once the voltage levels are adjusted, the energy is transferred to the electric motor. The electric motor then transfers that energy into the transmission and the resulting axles that power its propulsion.

The range of a fuel cell HDV depends on the payload but also the amount of hydrogen that is stored in the vehicle. A typical fuel cell HDV will be able to reach a range of 500-1000 miles with a single fueling session and two hydrogen tanks carrying 40-60 kg of hydrogen each at 350 bars [72]. Some aggregated drive cycle data indicate that hydrogen fuel consumption for a class 8 vehicle can range from 5.5 to 9.2 miles per $\mathrm{kg}$ of hydrogen [73]. The hydrogen refueling rate for heavy-duty trucks would be around $120 \mathrm{~g} / \mathrm{s}$ which would result in around a 16-min refueling time [74,75]. The tailpipe emissions of a fuel cell HDV, as with any zero-emission vehicles, will be zero. However, the available infrastructure for HFCVs is very scarce. At the end of 2018, there were only $370 \mathrm{H} 2$ refueling stations in operation globally, with most of them in Europe, Japan, and America [76]. The lack of infrastructure has resulted in high fuel costs and high vehicle capital costs. However, it is expected to be cheaper when greater infrastructure and more vehicles emerge. A major company in the heavy-duty sector called Cummins claims to have installed over 2000 on-and-off PEMFC applications across the globe [77].

The energy efficiency of a PEMFC stack is around 45\% [32]. The range lies around $40-60 \%$ depending on how it is built what it is composed of [78]. Cummins claims to have PEMFC efficiencies of 51-59\% [79]. Assuming all the energy is from renewable sources and considering all the transportation and energy losses, the overall energy efficiency would be around $23 \%$ [80]. The efficiency is greater than diesel's but is less than battery. The specific energy of hydrogen is around $32,702 \mathrm{Wh} / \mathrm{kg}$ or approximately $118 \mathrm{MJ} / \mathrm{kg}$ [13]. The fuel cell HDV goal is to reach a 25,000 h lifetime operating time, giving a range of about 500,000 miles or 12 years [81]. The fuel cell's service life is limited by the degradation mechanisms related to the catalyst and the membrane [82]. The end of life is typically categorized when the voltage degradation drops by $10 \%$ relative to the beginning of life voltage. The light-duty transportation goal of $5000 \mathrm{~h}$ has yet to be met, with an average of around 2000-3000 h [83,84]. Experimentally, there have been buses that have been shown to run over 25,000 h operating time [85]. There has not been much literature on fuel cell lifespan in freight applications. However, the lifetime of PEMFCs is often not reported 
as there is no agreement on the standard definition for durability due to differences in operating conditions.

\section{Recent Technological Developments in Fuel Cell Electric Heavy-Duty Vehicles}

Recently, fuel cell electric vehicles have shown growth, though still low in numbers, while battery electric vehicles have demonstrated stronger sales. Fuel cells carry the disadvantage of lower power density and lower power response comparing to other power sources. Thus, Hames et al. [86] developed a strategy where batteries, supercapacitors, and energy storage systems are used in conjunction with fuel cells to mitigate the disadvantages of fuel cells while maintaining the advantage of being a sustainable fuel source. In addition, the combination of various energy storage systems allows the vehicle to handle various situations as well through power-sharing between the systems. There are many strategies available for use, such as the Peaking Power Source Strategy, Operating Mode Control Strategy, Fuzzy Logic Control Strategy, and Equivalent Consumption Minimization Strategy. Among these strategies, the Equivalent Consumption Minimization Strategy is preferred as the consumption of energy is minimized while Fuzzy Logic Control Strategy is not preferred due to long computational times. Through modeling, Macauley et al. [81] successfully predicted the fuel cell membrane's lifetime within $20 \%$ of the actual operating time. Their model used cell voltage, temperature, oxygen concentration, and humidity cycling to determine the lifetime of a heavy-duty fuel cell for a Whistler bus transit fleet. With a goal of $25,000 \mathrm{~h}$ lifetime, the model predicted a lifetime of $17,500 \mathrm{~h}$. With the popularity of hydrogen fuel cells, Apostolou et al. [76] conducted a literature review on current-day hydrogen-related infrastructure and prospects. Currently, there are five hydrogen production methods available such as electrolysis, coal, heavy oil, natural gas reforming, and biomass. To accommodate the rising popularity of hydrogen vehicles, refueling stations should be built and consist of a production unit, purification unit, compressor, storage tanks, hydrogen gas booster, cooling unit, and other items. Gangloff et al. [87] assessed the space of hydrogen storage tanks and evaluated the efficiency of hydrogen compared to conventional vehicles. The state-of-the-art hydrogen technology uses compressed gas at $350-700$ bar and $50-80 \mathrm{~kg}$ of hydrogen. Since the efficiency of $1 \mathrm{~kg}$ hydrogen is almost equivalent to 1 gallon of conventional fuel, the current hydrogen tanks have similar ranges to conventional vehicles. To estimate the available range of a fuel cell vehicle, Chandrasekar et al. [88] were able to showcase several equations that estimated the range of a hydrogen fuel cell electric truck. Kast et al. [72] investigated the feasibility of hydrogen fuel cell drivetrains through the evaluation of the physical space inside medium to heavy-duty trucks available for hydrogen fuel cells. Various models were used to determine the available space and concluded that most trucks do not pose a size constrain on hydrogen fuel storage stored at 350-700 bars. Sim et al. [89] utilized Autonomie to optimize the combination of hydrogen and battery storage to maximize efficiency and minimize cost for class 4 and class 8 vehicles. Through Autonomie, the most efficient setup for a class 8 vehicle would have a battery capacity is $24.2 \mathrm{kWh}$ and fuel cell power of $391.0 \mathrm{~kW}$. Ogden et al. [90] evaluated the transition from natural gas to hydrogen and the possible issues that may occur. Using established natural gas infrastructure such as pipelines and refueling stations for hydrogen could be expensive as the usability might need to be evaluated individually. The blending of gasses might not be sustainable as well unless green hydrogen could be separated from the blend and injected into highly efficient fuel cell cars without increasing greenhouse gas emissions. Overall, a complete system that is fully dedicated to hydrogen will be needed if one were to truly achieve zero emissions.

\section{Comparison and Analysis of Diesel, Battery, and Fuel Cell Heavy-Duty Vehicles}

The criteria that are compared in Table 1 for the three HDV technologies are the tailpipe emissions, the tank-to-wheel efficiency, the fuel consumption, the range, the refueling/recharging time, and energy density. The tailpipe emissions are the emissions released due to work in the vehicle. The emissions to generate the electricity for hydrogen 
fuel cells and batteries were not considered. The tank-to-wheel efficiency is the energy efficiency of the process from the energy storage system inside the vehicle until it is converted into mechanical energy in the wheels. Fuel consumption is the distance that can be traveled per unit of the energy source. The range is a calculation of the distance that can be covered by a given truck for each technology. The refueling/recharging time is the time it takes for the energy storage system to meet its capacity. Lastly, the specific energy is the energy content for each type of fuel per $\mathrm{kg}$ of energy source. The lifespan was discussed in some of the previous sections but is not directly compared in this section due to insufficient literature.

Table 1. Comparison between three discussed heavy-duty vehicle powertrains.

\begin{tabular}{cccc}
\hline Criteria & Diesel & Battery & Hydrogen Fuel Cell \\
\hline Tailpipe emissions & Yes & No & No \\
Total vehicle cost ${ }^{1}$ & $119,000-134,000$ USD & $164,641-585,000$ USD & $135,503-249,900$ USD \\
Well-to-tank efficiency ${ }^{2}$ & $\sim 86 \%[91]$ & $\sim 55.3 \%[91]$ & $\sim 76 \%[91]$ \\
Tank-to-wheel efficiency & $\sim 23 \%[32]$ & $\sim 68 \%[32]$ & $\sim 45 \%[32]$ \\
Fuel consumption & 6.5 miles/gallon [24] & $0.5 \mathrm{miles} / \mathrm{kWh} \mathrm{[50]}$ & $5.5-9.2 \mathrm{miles} / \mathrm{kg} \mathrm{H}$ [73] \\
Range & $975-1950 \mathrm{miles}$ & $62-500 \mathrm{miles}$ & $660-1104 \mathrm{miles}$ \\
Refueling time & $6-12 \mathrm{~min}$ & $2.85-20 \mathrm{~h}$ & $16.67 \mathrm{~min}$ \\
Specific Energy & $42.9 \mathrm{MJ} / \mathrm{kg} \mathrm{[33]}$ & $0.432-0.792 \mathrm{MJ} / \mathrm{kg} \mathrm{[56]}$ & $118 \mathrm{MJ} / \mathrm{kg} \mathrm{[14]}$ \\
\hline
\end{tabular}

${ }^{1}$ The total vehicle costs were taken from a specific case study conducted for California. Reproduced from [92], UC Davis: National Center for Sustainable Transportation: 2020. ${ }^{2}$ The well-to-tank efficiencies of the fuels were of the same pathway (natural gas as the source) for comparative purposes.

Regarding Table 1, range depends on the fuel or energy onboard, which depends on the amount that the manufacturer decides to insert and were calculated based on the amount of energy on board. For diesel, it was based on 150-300 gallons of diesel fuel, which is typical. For battery, it was calculated off the typical $100 \mathrm{~km}$ range and a $1000 \mathrm{kWh}$ battery. For hydrogen fuel cells, it was based on $120 \mathrm{~kg}$ of hydrogen on board. Refueling time for diesel was calculated off a flow rate of 25 gallons/minute and a capacity of 150-300 gallons. Charging time depends on the infrastructure available. This calculation assumed a $50-350 \mathrm{~kW}$ charger. Refueling time for a hydrogen fuel cell vehicle is calculated off $120 \mathrm{~kg}$ of hydrogen and a flowrate of $120 \mathrm{~g} / \mathrm{s}$.

Table 1 shows that battery and hydrogen fuel cell HDVs both will emit zero tailpipe emissions. Regarding the total costs of vehicles, in the case study conducted in California by Burke et al. [92], it was found that all electrified long-haul and short-haul HDVs had higher total costs of ownership (TCOs) compared to their diesel counterparts in most pricing scenarios. Battery-electric HDVs were shown to have the highest vehicle cost of the three. Fuel cells were the most promising due to a greater nominal driving range. The TCOs of battery and hydrogen fuel HDVs in California can be competitive with diesel HDVs if the price of batteries and fuel cells drops to around $\$ 100 / \mathrm{kWh}$ for both technologies. This low price can potentially occur in the next 10 to 20 years as more technological advances are made toward improving these two powertrains. BEVs have the highest tank-to-wheel efficiency but have greater refueling time and lower specific energy than the ones that are diesel and hydrogen driven. HFCVs are comparable to diesel in refueling time and well-to-tank efficiency. The total efficiency, which is the product of well-to-tank efficiency and tank-to-wheel efficiency, is comparable between BEVs and HFCVs (37.6 and 34.2\%, respectively), and both are significantly higher than the total efficiency of diesel HDVs $(19.8 \%)$. As well, the higher capacity end of HFCVs could drive to similar ranges as the lower capacities of diesel with less weight on board due to their high specific energy. BEVs fall short in refueling time, range, and specific energy in comparison to diesel and hydrogen fuel cell trucks.

Table 2 displays a more qualitative analysis of the advantages and disadvantages of the powertrains. Diesel HDV technology's advantages are that they have the lowest capital costs as they are the most widely available fuel and engine technology in heavyduty environments. There would be no additional infrastructure needed. However, the 
disadvantages are that they emit greenhouse gases and are not very energy efficient. Regarding battery technology, the advantages are that it has greater efficiency, lower emissions than diesel, lower maintenance costs than diesel, and requires less infrastructure than fuel cell technology. However, the disadvantages are that it has higher vehicle costs than diesel, higher infrastructure costs than diesel, limited range, and has limited payload due to the weight and size of the battery. Regarding fuel cell technology, the advantages are that it has lower emissions, greater efficiency than diesel, better refueling time than batteries, and has a greater specific energy. However, the disadvantages are that fuel cell vehicles currently have the highest costs, the most infrastructure development requirements, and the slowest technological development.

Table 2. Advantages and disadvantages of the three powertrains.

\begin{tabular}{|c|c|c|}
\hline Technology & Advantages & Disadvantages \\
\hline \multirow{4}{*}{ Diesel } & \multirow{4}{*}{$\begin{array}{l}\text { Lowest vehicle cost. } \\
\text { No infrastructure investment required. } \\
\text { Long range and high payload. } \\
\text { Faster refueling time than BEVs. } \\
\text { Large market with widely available parts and vehicles. }\end{array}$} & High greenhouse gas emissions \\
\hline & & Source of local air pollution (high tailpipe emissions). \\
\hline & & High refueling and maintenance cost. \\
\hline & & Low energy efficiency. \\
\hline \multirow{6}{*}{ Battery } & \multirow{6}{*}{$\begin{array}{l}\text { Reduces greenhouse gas emissions. } \\
\text { Reduces local air pollution (no tailpipe emissions). } \\
\text { Lower refueling and maintenance costs than } \\
\text { ICE vehicles. } \\
\text { Higher energy efficiency than ICE. } \\
\text { Less infrastructure investment required than FCEV. }\end{array}$} & Infrastructure investment required. \\
\hline & & Higher vehicle cost than diesel. \\
\hline & & Long recharging time. \\
\hline & & \\
\hline & & Limited range. \\
\hline & & Limited cargo weight and size due to large battery. \\
\hline \multirow{4}{*}{ Fuel cell } & \multirow{4}{*}{$\begin{array}{l}\text { Reduces greenhouse gas emissions. } \\
\text { Reduces local air pollution (no tailpipe emissions). } \\
\text { Higher energy efficiency than ICE. } \\
\text { Faster refueling time than BEVs. } \\
\text { High specific energy. }\end{array}$} & High initial hydrogen fuel cost. \\
\hline & & Heavy infrastructure development required. \\
\hline & & Highest vehicle cost compared to diesel or battery. \\
\hline & & Slow FCEV development. \\
\hline
\end{tabular}

Regarding diesel HDVs, a suggestion for future research would be to find ways to reduce the emissions of a given vehicle. This could be done through ways such as improving after-treatment processes, reducing fuel consumption through better efficiency or techniques, and trying different fuel mixes. There are also significant studies being performed in hybrid diesel heavy-duty powertrains that could ease the transition into a fully electrified fleet $[93,94]$. Regarding battery technology, Battery HDVs are more suitable for lighter duty and shorter haul applications due to their limited range and payload capacity. A suggestion for future research would be to maximize the power and energy density of the battery [95]. The use of solid-state batteries, which have the potential to increase battery energy and power densities, is currently investigated intensively [96]. Furthermore, better battery management systems [97] and fast charging technologies [98] should be considered. Hydrogen fuel cell HDVs are comparable in performance to the average diesel HDVs due to their similar range and power capabilities. However, there is a lot of work needed to be done, especially with the lack of infrastructure. A suggestion for future research would be to find ways to produce and store hydrogen safely and renewably at low cost [99]. Further research and development into the continuous improvement of fuel cell technology are also necessary [100]. Furthermore, studies on the cost estimation of the necessary infrastructure and distribution for hydrogen would aid policymakers to ease hydrogen technology into the public sphere [101].

\section{Conclusions}

Climate change, pollution, and negative health impacts are some of the main concerns with the rise of greenhouse gas emissions. HDVs are one of the main contributors to transportation-related greenhouse gas emissions, hence, many groups are working to 
mitigate emissions across the freight transportation sector. Most HDVs nowadays use diesel compression-ignition engines due to their greater energy efficiency than gasoline. However, many kinds of emissions are still released during diesel combustion, including $\mathrm{CO}_{2}, \mathrm{NO}_{\mathrm{x}}$, and PM. Therefore, the proposal of lower emission and zero-emission HDVs has been made and worked toward. Battery electric HDVs and hydrogen fuel cell HDVs stand out in all the available alternatives to diesel engines. In this work, we conducted a comprehensive review to examine the working mechanism, performance metrics, and recent developments of diesel engine HDVs, battery-electric HDVs, and hydrogen fuel cell HDVs. A detailed comparison between the three technologies was also discussed, along with the future perspectives of the HDV sector. The diesel engines in HDVs will remain an important technology in the short-term future and continue to be advantageous due to the already existing infrastructure and available trucks worldwide, which result in lower costs. On the other hand, they still emit a lot of greenhouse gases. Battery electric HDV technology is advantageous due to its zero emissions and high efficiency, but it lacks in power and energy density which increases its size and limits payload and range. Hydrogen fuel cell HDV technology is advantageous due to its zero emissions, high specific energy, and comparable ranges to diesel trucks. However, it lacks the available infrastructure and requires high capital to set up. Since governments have a key role in advancing zero-emission vehicles, the information presented in this study will be useful for decisionmakers in governments who are trying to decide the appropriate future direction for HDV powertrain developments. Exploring bigger, bolder, and infrastructure-intensive options such as battery HDVs and fuel cell HDVs is necessary to better understand the costs, benefits, and viability of these technology options for widespread applications. Because of the complexity of the HDV sector, a mix of cleaner technologies, including hybrid, battery, and fuel cell, will ultimately be needed for long-term decarbonization.

Author Contributions: Conceptualization, C.C., M.-K.T., and M.F.; methodology, C.C. and M.K.T.; formal analysis, C.C. and Y.L.; resources, C.C., Y.L., S.K., and V.L.; writing-original draft preparation, C.C., Y.L., S.K., and V.L.; writing-review and editing, M.-K.T. and M.F.; visualization, Y.L.; supervision, M.F.; funding acquisition, M.F. All authors have read and agreed to the published version of the manuscript.

Funding: This research received no external funding.

Institutional Review Board Statement: Not applicable.

Informed Consent Statement: Not applicable.

Data Availability Statement: Not applicable.

Acknowledgments: This work was supported by the Department of Chemical Engineering at the University of Waterloo, Canada Research Chair Tier I-Zero-Emission Vehicles and Hydrogen Energy Systems Grant number: 950-232215, and The Natural Sciences and Engineering Research Council of Canada (NSERC), Discovery Grants Program, RGPIN-2020-04149.

Conflicts of Interest: The authors declare no conflict of interest.

\section{References}

1. Muncrief, R.; Sharpe, B. Overview of the Heavy-Duty Vehicle Market and $\mathrm{CO}_{2}$ Emissions in the European Union; International Council on Clean Transportation: Washington, DC, USA, 2015; pp. 1-14.

2. Aldhafeeri, T.; Tran, M.-K.; Vrolyk, R.; Pope, M.; Fowler, M. A Review of Methane Gas Detection Sensors: Recent Developments and Future Perspectives. Inventions 2020, 5, 28. [CrossRef]

3. Posada, F.; Yang, Z.; Muncrief, R. Review of Current Practices and New Developments in Heavy-Duty Vehicle Inspection and Maintenance Programs; International Council on Clean Transportation: Washington, DC, USA, 2015.

4. Environmental Protection Agency. Fast Facts on Transportation Greenhouse Gas Emissions. Green Vehicle Guide. Available online: https:/ / www.epa.gov / greenvehicles/fast-facts-transportation-greenhouse-gas-emissions (accessed on 3 February 2021).

5. Tran, M.-K.; Sherman, S.; Samadani, E.; Vrolyk, R.; Wong, D.; Lowery, M.; Fowler, M. Environmental and Economic Benefits of a Battery Electric Vehicle Powertrain with a Zinc-Air Range Extender in the Transition to Electric Vehicles. Vehicles 2020, 2, 398-412. [CrossRef] 
6. Alternative Fuels Data Center: Maps and Data-Vehicle Weight Classes \& Categories. Available online: https://afdc.energy.gov / data/10380 (accessed on 5 February 2021).

7. Kalghatgi, G. Development of Fuel/Engine Systems-The Way Forward to Sustainable Transport. Engineering 2019, 5, 510-518. [CrossRef]

8. Posada, F.; Chambliss, S.; Blumberg, K. Costs of Emission Reduction Technologies for Heavy-Duty Diesel Vehicles; International Council on Clean Transportation: Washington, DC, USA, 2016; p. 39.

9. Kluschke, P.; Gnann, T.; Plötz, P.; Wietschel, M. Market diffusion of alternative fuels and powertrains in heavy-duty vehicles: A literature review. Energy Rep. 2019, 5, 1010-1024. [CrossRef]

10. Tran, M.-K.; Akinsanya, M.; Panchal, S.; Fraser, R.; Fowler, M. Design of a Hybrid Electric Vehicle Powertrain for Performance Optimization Considering Various Powertrain Components and Configurations. Vehicles 2021, 3, 20-32. [CrossRef]

11. Liu, Z. Overview of heavy-duty diesel engines. In Advanced Direct Injection Combustion Engine Technologies and Development; Woodhead Publishing: Cambridge, UK; Sawston, UK, 2010; pp. 269-288. [CrossRef]

12. Tran, M.-K.; Mevawala, A.; Panchal, S.; Raahemifar, K.; Fowler, M.; Fraser, R. Effect of integrating the hysteresis component to the equivalent circuit model of Lithium-ion battery for dynamic and non-dynamic applications. J. Energy Storage 2020, $32,101785$. [CrossRef]

13. Tran, M.-K.; Fowler, M. Sensor Fault Detection and Isolation for Degrading Lithium-Ion Batteries in Electric Vehicles Using Parameter Estimation with Recursive Least Squares. Batteries 2020, 6, 1. [CrossRef]

14. Pelletier, S.; Jabali, O.; Laporte, G. Battery Electric Vehicles for Goods Distribution: A Survey of Vehicle Technology, Market Penetration, Incentives and Practices; Cirrelt: Montreal, QC, Canada, 2014; p. 51.

15. Staffell, I.; Scamman, D.; Abad, V.; Balcombe, P.; Dodds, P.E.; Ekins, P.; Ward, K.R. The role of hydrogen and fuel cells in the global energy system. Energy Environ. Sci. 2019, 12, 463-491. [CrossRef]

16. Cai, H.; Burnham, A.; Chen, R.; Wang, M. Wells to wheels: Environmental implications of natural gas as a transportation fuel. Energy Policy 2017, 109, 565-578. [CrossRef]

17. Shin, J.; Hwang, W.S.; Choi, H. Can hydrogen fuel vehicles be a sustainable alternative on vehicle market? Comparison of electric and hydrogen fuel cell vehicles. Technol. Forecast. Soc. Chang. 2019, 143, 239-248. [CrossRef]

18. Zhao, H.; Burke, A.; Miller, M. Analysis of Class 8 truck technologies for their fuel savings and economics. Transp. Res. Part D Transp. Environ. 2013, 23, 55-63. [CrossRef]

19. Sen, B.; Ercan, T.; Tatari, O. Does a battery-electric truck make a difference?-Life cycle emissions, costs, and externality analysis of alternative fuel-powered Class 8 heavy-duty trucks in the United States. J. Clean. Prod. 2017, 141, 110-121. [CrossRef]

20. Smallbone, A.; Jia, B.; Atkins, P.; Roskilly, A.P. The impact of disruptive powertrain technologies on energy consumption and carbon dioxide emissions from heavy-duty vehicles. Energy Convers. Manag. X 2020, 6. [CrossRef]

21. Department of Energy. Internal Combustion Engine Basics. Available online: https://www.energy.gov/eere/vehicles/articles/ internal-combustion-engine-basics (accessed on 25 February 2021).

22. Dell, R.M.; Moseley, P.T.; Rand, D.A.J. Development of Road Vehicles with Internal-Combustion Engines. In Towards Sustainable Road Transport; Academic Press: Oxford, UK; Waltham, MA, USA, 2014; ISBN 9780124046160.

23. Putzig, M.; Gonzalez, J.; Moriarty, K.; Bennett, J.; Brown, A.; Rahill, M. Alternative Fuels Data Center Fuel Properties Comparison. Available online: https://afdc.energy.gov / files/u/publication/fuel_comparison_chart.pdf (accessed on 8 February 2021).

24. Schoettle, B.; Sivak, M.; Tunnell, M. A Survey of Fuel Economy and Fuel Usage by Heavy-Duty Truck Fleets; American Transportation Research Institute: Arlington, VA, USA, 2016; p. 58.

25. H2@Ports Workshop Summary Report. 2019. Available online: https://publications.anl.gov/anlpubs/2020/03/158750.pdf (accessed on 8 February 2021).

26. Greim, H. Diesel engine emissions: Are they no longer tolerable? Arch. Toxicol. 2019, 93. [CrossRef]

27. Clark, N.N.; Kern, J.M.; Atkinson, C.M.; Nine, R.D. Factors affecting heavy-duty diesel vehicle emissions. J. Air Waste Manag. Assoc. 2002, 52, 84-94. [CrossRef] [PubMed]

28. Seo, J.; Park, J.; Oh, Y.; Park, S. Estimation of total transport $\mathrm{CO}_{2}$ emissions generated by medium-and heavy-duty vehicles (MHDVs) in a sector of Korea. Energies 2016, 9, 638. [CrossRef]

29. Carbon Calculator Emission Factors. Available online: https://www.cn.ca/repository/popups/ghg/Carbon-CalculatorEmission-Factors (accessed on 12 February 2021).

30. Badshah, H.; Posada, F.; Muncrief, R. Current State of NOx Emissions From In-Use Heavy-Duty Diesel Vehicles in the United States; International Council on Clean Transportation: Washington, DC, USA, 2019; p. 36.

31. ACEA-European Automobile Manufacturers' Association. Fuel Types of New Trucks: Diesel 97.9\%, Electric 0.2\%, Hybrid 0.1\% Market Share in 2019. Available online: https:/ / www.acea.be/press-releases/article/fuel-types-of-new-trucks-diesel-97.9 -electric-0.2-hybrid-0.1-market-share-i (accessed on 16 February 2021).

32. Huang, W.D.; Zhang, Y.H.P. Energy efficiency analysis: Biomass-to-wheel efficiency related with biofuels production, fuel distribution, and powertrain systems. PLoS ONE 2011, 6, 1-10. [CrossRef]

33. Wu, T.; Huang, Z.; Zhang, W.; Fang, J.; Yin, Q. Physical and Chemical Properties of GTL—Diesel Fuel Blends and Their Effects on Performance and Emissions of a Multicylinder DI Compression Ignition Engine. Energy Fuels 2007, 21, 1908-1914. [CrossRef]

34. Bhoopalam, A.K.; Agatz, N.; Zuidwijk, R. Planning of truck platoons: A literature review and directions for future research. Transp. Res. Part B Methodol. 2018, 107, 212-228. [CrossRef] 
35. Peng, M.; Lin, J.; Liu, X. Optimizing Design of Powertrain Transmission Ratio of Heavy Duty Truck. IFAC PapersOnLine 2018, 51, 892-897. [CrossRef]

36. Henriksson, M.; Flardh, O.; Jonas, M. Optimal Powertrain Control of a Heavy-Duty Vehicle Under Varying Speed Requirements Department of Automatic Control. In Proceedings of the 2017 IEEE 20th International Conference on Intelligent Transportation Systems (ITSC), Yokohama, Japan, 16-19 October 2017.

37. Emanuele, S.; Barro, C.; Boulouchos, K.; Burger, J. POMDME-diesel blends: Evaluation of performance and exhaust emissions in a single cylinder heavy-duty diesel engine. Fuel 2017, 203, 57-67. [CrossRef]

38. Ramesh, A.K.; Gosala, D.B.; Allen, C.; Mccarthy, J.; Eaton, J.; Farrell, L. Cylinder Deactivation for Increased Engine Efficiency and Aftertreatment Thermal Management in Diesel Engines. In SAE Technical Paper; SAE International: Warrendalte, PA, USA, 2018; pp. 1-10. [CrossRef]

39. Shim, E.; Park, H.; Bae, C. Comparisons of advanced combustion technologies (HCCI, PCCI, and dual-fuel PCCI) on engine performance and emission characteristics in a heavy-duty diesel engine. Fuel 2020, 262, 116436. [CrossRef]

40. Xu, B.; Rathod, D.; Yebi, A.; Filipi, Z.; Onori, S.; Ho, M. A comprehensive review of organic rankine cycle waste heat recovery systems in heavy-duty diesel engine applications. Renew. Sustain. Energy Rev. 2019, 107, 145-170. [CrossRef]

41. Vos, K.; Shaver, G.; Lu, X.; Allen, C.; McCarthy, J.; Farrell, L. Improving diesel engine efficiency at high speeds and loads through improved breathing via delayed intake valve closure timing. Int. J. Engine Res. 2019, 20, 194-202. [CrossRef]

42. Hlasny, T.; Fanti, M.P.; Mangini, A.M.; Rotunno, G.; Turchiano, B. Optimal fuel consumption for heavy trucks: A review. In Proceedings of the 2017 IEEE International Conference on Service Operations and Logistics, and Informatics (SOLI), Bari, Italy, 18-20 September 2017; pp. 80-85. [CrossRef]

43. Mevawalla, A.; Panchal, S.; Tran, M.-K.; Fowler, M.; Fraser, R. One dimensional fast computational partial differential model for heat transfer in lithium-ion batteries. J. Energy Storage 2021, 37, 102471. [CrossRef]

44. Panchal, S.; Gudlanarva, K.; Tran, M.-K.; Fraser, R.; Fowler, M. High Reynold's Number Turbulent Model for Micro-Channel Cold Plate Using Reverse Engineering Approach for Water-Cooled Battery in Electric Vehicles. Energies 2020, 13, 1638. [CrossRef]

45. Tran, M.-K.; Fowler, M. A Review of Lithium-Ion Battery Fault Diagnostic Algorithms: Current Progress and Future Challenges. Algorithms 2020, 13, 62. [CrossRef]

46. Wen, J.P.; Zhang, C.W. Research on modeling and control of regenerative braking for brushless dc machines driven electric vehicles. Math. Probl. Eng. 2015, 2015. [CrossRef]

47. Tran, M.-K.; Bhatti, A.; Vrolyk, R.; Wong, D.; Panchal, S.; Fowler, M.; Fraser, R. A Review of Range Extenders in Battery Electric Vehicles: Current Progress and Future Perspectives. World Electr. Veh. J. 2021, 12, 54. [CrossRef]

48. Moultak, M.; Lutsey, N.; Hall, D. Transitioning to Zero-Emission Heavy-Duty Freight Vehicles; International Council on Clean Transportation: Washington, DC, USA, 2017; p. 53.

49. Earl, T.; Mathieu, L.; Cornelis, S.; Kenny, S.; Ambel, C.C.; Nix, J. Analysis of long haul battery electric trucks in EU. In Proceedings of the 8th Commercial Vehicle Workshop, Graz, Austria, 17-18 May 2018; pp. 17-18.

50. Kalghatgi, G. Is it really the end of internal combustion engines and petroleum in transport? Appl. Energy 2018, 225, 965-974. [CrossRef]

51. Han, X.; Lu, L.; Zheng, Y.; Feng, X.; Li, Z.; Li, J.; Ouyang, M. A review on the key issues of the lithium ion battery degradation among the whole life cycle. ETransportation 2019, 1, 100005. [CrossRef]

52. Liimatainen, H.; van Vliet, O.; Aplyn, D. The potential of electric trucks-An international comodity-level analysis. Appl. Energy 2019, 236, 804-814. [CrossRef]

53. Lambert, F. Tesla Is in Talks with Electric Truck Customers to Install "Megacharger" Stations, Report Says-Electrek. Available online: https:/ /electrek.co/2018/02/02/tesla-semi-electric-truck-customers-megacharger-charging-station/ (accessed on 26 February 2021).

54. Gallo, J.-B. Electric Truck \& Bus Grid Integration, Opportunities, Challenges \& Recommendations. World Electr. Veh. J. 2016, 8, 45-56. [CrossRef]

55. Alternative Fuels Data Center. Alternative Fueling Station Locator. Available online: https://afdc.energy.gov/stations/\#/ analyze?country=US\&fuel=ELEC\&ev_levels=all (accessed on 12 March 2021).

56. Shen, X.; Liu, H.; Cheng, X.; Yan, C.; Huang, J. Beyond lithium ion batteries: Higher energy density battery systems based on lithium metal anodes. Energy Storage Mater. 2018, 12, 161-175. [CrossRef]

57. Saxena, S.; Le Floch, C.; Macdonald, J.; Moura, S. Quantifying EV battery end-of-life through analysis of travel needs with vehicle powertrain models. J. Power Sources 2015, 282, 265-276. [CrossRef]

58. Mevawalla, A.; Panchal, S.; Tran, M.-K.; Fowler, M.; Fraser, R. Mathematical Heat Transfer Modeling and Experimental Validation of Lithium-Ion Battery Considering: Tab and Surface Temperature, Separator, Electrolyte Resistance, Anode-Cathode Irreversible and Reversible Heat. Batteries 2020, 6, 61. [CrossRef]

59. Mareev, I.; Becker, J.; Sauer, D.U. Battery dimensioning and life cycle costs analysis for a heavy-duty truck considering the requirements of long-haul transportation. Energies 2018, 11, 55. [CrossRef]

60. Verbruggen, F.J.R.; Rangarajan, V.; Hofman, T. Powertrain design optimization for a battery electric heavy-duty truck. In Proceedings of the 2019 American Control Conference (ACC), Philadelphia, PA, USA, 10-12 July 2019; pp. 1488-1493. [CrossRef]

61. Ghandriz, T.; Jacobson, B.; Laine, L.; Hellgren, J. Impact of automated driving systems on road freight transport and electrified propulsion of heavy vehicles. Transp. Res. Part C Emerg. Technol. 2020, 115, 102610. [CrossRef] 
62. Schulte, J. Electric Road Systems: Strategic Stepping Stone on the Way towards Sustainable Freight Transport? Sustainability 2018, 10, 1148. [CrossRef]

63. Sen, B.; Kucukvar, M.; Onat, N.C.; Tatari, O. Life cycle sustainability assessment of autonomous heavy-duty trucks. J. Ind. Ecol. 2019, 24, 1-16. [CrossRef]

64. Mareev, I.; Sauer, D.U. Energy Consumption and Life Cycle Costs of Overhead Catenery Heavy-Duty Trucks for Long-Haul Transportation. Energies 2020, 11, 3446. [CrossRef]

65. Wolff, S.; Kalt, S.; Bstieler, M.; Lienkamp, M. Influence of Powertrain Topology and Electric Machine Design on Efficiency of Battery Electric Trucks-A Simulative. Energies 2021, 14, 328. [CrossRef]

66. Fuel Cell \& Hydrogen Energy Association. Fuel Cell Basics. Available online: http://www.fchea.org/fuelcells (accessed on 26 February 2021).

67. Tanc, B.; Arat, H.T.; Baltacioglu, E.; Aydun, K. Overview of the next quarter century vision of hydrogen fuel cell electric vehicles. Int. J. Hydrog. Energy 2019, 44, 10120-10128. [CrossRef]

68. Ahmadi, P.; Kjeang, E. Realistic simulation of fuel economy and life cycle metrics for hydrogen fuel cell vehicles. Int. J. Energy Res. 2017, 41, 714-727. [CrossRef]

69. Bauman, J.; Kazerani, M. A comparative study of fuel-cell-battery, fuel-cell-ultracapacitor, and fuel-cell-battery-ultracapacitor vehicles. IEEE Trans. Veh. Technol. 2008, 57, 760-769. [CrossRef]

70. Marzougui, H.; Amari, M.; Kadri, A.; Bacha, F.; Ghouili, J. Energy management of fuel cell/battery/ultracapacitor in electrical hybrid vehicle. Int. J. Hydrog. Energy 2017, 42, 8857-8869. [CrossRef]

71. Zhao, H.; Burke, A.; Zhu, L. Analysis of Class 8 hybrid-electric truck technologies using diesel, LNG, electricity, and hydrogen, as the fuel for various applications. In Proceedings of the 2013 World Electric Vehicle Symposium and Exhibition (EVS27), Barcelona, Spain, 17-20 November 2013; pp. 1-16. [CrossRef]

72. Kast, J.; Morrison, G.; Gangloff, J.J.; Vijayagopal, R.; Marcinkoski, J. Designing hydrogen fuel cell electric trucks in a diverse medium and heavy duty market. Res. Transp. Econ. 2018, 70, 139-147. [CrossRef]

73. Kast, J.; Vijayagopal, R.; Gangloff, J.J.; Marcinkoski, J. Clean commercial transportation: Medium and heavy duty fuel cell electric trucks. Int. J. Hydrog. Energy 2017, 42, 4508-4517. [CrossRef]

74. SAE Mobilus. Fueling Protocol for Gaseous Hydrogen Powered Heavy Duty Vehicles (J2601/2 Ground Vehicle Standard). Available online: https:/ / saemobilus.sae.org/content/j2601/2_201409 (accessed on 26 February 2021).

75. Refueling Protocols for Medium and Heavy-Duty Vehicles. Available online: https://ec.europa.eu/info/funding-tenders/ opportunities/portal/screen/opportunities/topic-details/fch-04-2-2019 (accessed on 26 February 2021).

76. Apostolou, D.; Xydis, G. A literature review on hydrogen refuelling stations and infrastructure. Current status and future prospects. Renew. Sustain. Energy Rev. 2019, 113, 109292. [CrossRef]

77. Cummins Inc. Hydrogen: From Firsts to Fruition. Available online: https://www.cummins.com/news/2020/04/21/hydrogenfirsts-fruition (accessed on 12 March 2021).

78. Ahmed, K.; Farrok, O.; Rahman, M.M.; Ali, M.S.; Haque, M.M.; Azad, A.K. Proton Exchange Membrane Hydrogen Fuel Cell as the Grid Connected Power Generator. Energies 2020, 13, 6679. [CrossRef]

79. Cummins Inc. Fuel Cell. Available online: https://www.cummins.com/new-power/technology/fuel-cell (accessed on 12 March 2021).

80. Tsakiris, A. Analysis of hydrogen fuel cell and battery efficiency. In Proceedings of the Young Energy Researchers Conference, Wels, Austria, 27 February-1 March 2019; pp. 1-8.

81. Macauley, N.; Watson, M.; Lauritzen, M.; Knights, S.; Wang, G.G.; Kjeang, E. Empirical membrane lifetime model for heavy duty fuel cell systems. J. Power Sources 2016, 336, 240-250. [CrossRef]

82. Dubau, L.; Castanheira, L.; Maillard, F.; Chatenet, M.; Lottin, O.; Maranzana, G.; Dillet, J.; Lamibrac, A.; Perrin, J.C.; Moukheiber, E.; et al. A review of PEM fuel cell durability: Materials degradation, local heterogeneities of aging and possible mitigation strategies. Wiley Interdiscip. Rev. Energy Environ. 2014, 3, 540-560. [CrossRef]

83. Robin, C.; Gerard, M.; Franco, A.A.; Schott, P. Multi-scale coupling between two dynamical models for PEMFC aging prediction. Int. J. Hydrog. Energy 2013, 38, 4675-4688. [CrossRef]

84. Jouin, M.; Bressel, M.; Morando, S.; Gouriveau, R.; Péra, M.; Zerhouni, N.; Jemei, S.; Hilairet, M.; Jouin, M.; Bressel, M.; et al. Estimating the end-of-life of PEM fuel cells: Guidelines and metrics. Appl. Energy 2016, 177. [CrossRef]

85. Adams, J. DOE H2 Heavy Duty Truck Targets. In Proceedings of the Compressed Gas Storage for Medium and Heavy Duty Transportation Workshop, Dayton, OH, USA, 21 January 2020.

86. Hames, Y.; Kaya, K.; Baltacioglu, E.; Turksoy, A. Analysis of the control strategies for fuel saving in the hydrogen fuel cell vehicles. Int. J. Hydrog. Energy 2018, 43, 10810-10821. [CrossRef]

87. Gangloff, J.J.; Kast, J.; Morrison, G.; Marcinkoski, J. Design Space Assessment of Hydrogen Storage Onboard Medium and Heavy Duty Fuel Cell Electric Trucks. J. Electrochem. Energy Convers. Storage 2017, 14. [CrossRef]

88. Chandrasekar, C.V.; Kumar, L.A. A Novel Approach on Range Prediction of a Hydrogen Fuel Cell Electric Truck. In SAE Technical Paper; SAE International: Warrendalte, PA, USA, 2021. [CrossRef]

89. Sim, K.; Vijayagopal, R.; Kim, N.; Rousseau, A. Optimization of component sizing for a fuel cell-powered truck to minimize ownership cost. Energies 2019, 12, 1125. [CrossRef] 
90. Ogden, J.; Jaffe, A.M.; Scheitrum, D.; McDonald, Z.; Miller, M. Natural gas as a bridge to hydrogen transportation fuel: Insights from the literature. Energy Policy 2018, 115, 317-329. [CrossRef]

91. Edwards, R.; Larivé, J.F.; Beziat, J.C. Well-To-Wheels Analysis of Future Automotive Fuels and Power Trains in the European Context; Publications Office: Luxembourg, 2011.

92. Burke, A.; Sinha, A.K. Technology, Sustainability, and Marketing of Battery Electric and Hydrogen Fuel Cell Medium-Duty and Heavy-Duty Trucks and Buses in 2020-2040; UC Davis; National Center for Sustainable Transportation: Davis, CA, USA, 2020.

93. Russell, R.L.; Johnson, K.; Durbin, T.; Chen, P.P.; Tomic, J.; Parish, R. Emissions, Fuel Economy, and Performance of a Class 8 Conventional and Hybrid Truck. In SAE Technical Paper; SAE International: Warrendalte, PA, USA, 2015. [CrossRef]

94. Karbowski, D.; Delorme, A.; Rousseau, A. Modeling the hybridization of a class 8 line-haul truck. In SAE Technical Paper; SAE International: Warrendalte, PA, USA, 2010. [CrossRef]

95. Li, J.; Du, Z.; Ruther, R.E.; An, S.J.; David, L.A.; Hays, K.; Wood, M.; Phillip, N.D.; Sheng, Y.; Mao, C.; et al. Toward Low-Cost, High-Energy Density, and High-Power Density Lithium-Ion Batteries. JOM 2017, 69, 1484-1496. [CrossRef]

96. Zhang, W.; Nie, J.; Li, F.; Wang, Z.L.; Sun, C. A durable and safe solid-state lithium battery with a hybrid electrolyte membrane. Nano Energy 2018, 45, 413-419. [CrossRef]

97. Liu, K.; Li, K.; Peng, Q.; Zhang, C. A brief review on key technologies in the battery management system of electric vehicles. Front. Mech. Eng. 2019, 14, 47-64. [CrossRef]

98. Tomaszewska, A.; Chu, Z.; Feng, X.; O’Kane, S.; Liu, X.; Chen, J.; Ji, C.; Endler, E.; Li, R.; Liu, L.; et al. Lithium-ion battery fast charging: A review. eTransportation 2019, 1, 100011. [CrossRef]

99. Dincer, I.; Acar, C. Review and evaluation of hydrogen production methods for better sustainability. Int. J. Hydrog. Energy 2014, 40, 11094-11111. [CrossRef]

100. Edwards, P.P.; Kuznetsov, V.L.; David, W.I.F.; Brandon, N.P. Hydrogen and fuel cells: Towards a sustainable energy future. Energy Policy 2008, 36, 4356-4362. [CrossRef]

101. Shamsi, H.; Tran, M.K.; Akbarpour, S.; Maroufmashat, A.; Fowler, M. Macro-Level optimization of hydrogen infrastructure and supply chain for zero-emission vehicles on a canadian corridor. J. Clean. Prod. 2020, 289, 125163. [CrossRef] 